\title{
Clinical Chemistry Finding
}

National Cancer Institute

\section{Source}

National Cancer Institute. Clinical Chemistry Finding. NCI Thesaurus. Code C70922.

The results of any chemical or enzymatic analyses of body fluids and tissues of an organism. 